\title{
MODEL DINAMIS DALAM MEMPREDIKSI TIMBULAN SAMPAH RUMAH TANGGA DI KOTA BAUBAU
}

\section{A DYNAMIC MODEL ON PREDICTIONOF MUNICIPAL SOLID WASTE IN BAUBAU}

\author{
Nurfatmala ${ }^{1}$, Anwar Mallongi ${ }^{2}$, Agus Bintara Birawida ${ }^{3}$ \\ ${ }^{1}$ Program Studi Ilmu Kesehatan Masyarakat Universitas Hasanuddin \\ ${ }^{2,3}$ Bagian Kesehatan Lingkungan Fakultas Kesehatan Masyarakat Universitas Hasanuddin
}

\author{
Alamat Korespondensi: Nurfatmala, Fakultas Kesehatan Masyarakat, Universitas \\ Hasanuddin Makassar, Telp:085299183021, Email: \\ nurfatmala92@gmail.com
}

\begin{abstract}
Abstrak
Sampah sering dianggap sebagai masalah dalam kehidupan manusia. Di satu sisi sampah merupakan bahan- bahan yang tidak bernilai ekonomis sehingga dibuang, disisi lain ada pihak yang menganggap sampah sebagai barang berguna. Penelitian ini bertujuan mengestimasi timbulan sampah diKota Baubau selama 25 tahun (2017- 2042) dan efektifias skenario model timbulan sampah dengan pendekatan model dinamis.Jenis penelitian adalah Cross Sectional dengan pendekatan model sistem dinamis yakni pengumpulan data untuk mendesain model yang bertujuan mendeskripsikan dan prediksi ke depan timbulan sampah rumah tangga di Kota Baubau. Populasi dalam penelitian ini adalah seluruh rumah yang ada di delapan kelurahan tersebut.Sampel dalam penelitian ini adalah rumah yang berada di kelurahan yang terpilih dengan prosedur simple random sampling dan besar sampel 359 rumah. Analisis data yaitu analisis sistem dinamis dengan menggunakan program Stella 5.0. Pemodelan dinamik diawali dengan membangun Diagram Alir Model Timbulan sampah. Hasil penelitian ini untuk skenario I timbulan sampah rumah tangga 25 tahun yang akan datang (2017-2042) meningkat sebesar 0,99 kali lipat. Skenario II menurunkan timbulan sampah rumah tangga 25 tahun yang akan datang (2017-2042) sebesar 1,01 kali lipat. Skenario III menurunkan timbulan sampah rumah tangga 25 tahun yang akan datang (2017-2042) sebesar 2 kali lipat. Skenario IV menurunkan timbulan sampah rumah tangga 25 tahun yang akan datang (2017-2042) sebesar 2,82 kali lipat. Skenario ini lebih efektif menekan jumlah timbulan sampah rumah tangga dibandingkan dengan skenario pesimis dan moderat. Disimpulkan estimasi rata - rata timbulan sampah rumah tangga di Kota Baubau, berdasarkan hasil simulasi model dinamis selama 25 tahun (2017-2042) dengan skenario bank sampah, akan mengalami penurunan sebesar 1,01 kali lipat dari total sampah.
\end{abstract}

Kata kunci : Estimasi, Model Dinamik, Timbulan Sampah Rumah Tangga.

\begin{abstract}
Garbage is often regarded as a problem in human life. On the one side, the waste is a material that is not economically valuable so thrown, on the other side, there are those who consider waste as a useful item. This study aims to estimate waste generation in Baubau City for 25 years (2017-2042) and effectiveness of waste generation model scenario with dynamic model approach. The research type is Cross Sectional with dynamic system model approach to describe and predict the forward household waste disposal in Baubau City. The population in this study is all the houses in the eight subdistricts (kelurahan). The samples in this study is a house in the selected village with simple random sampling procedures and the sample size is 359 houses. Data analysis is using Stella 5.0 program. Dynamic modeling begins with building a Flow Chart of Garbage Generation Model. The results of this study for scenario I household waste generation 25 years to come (2017-2042) increased by 0.99 times. Scenario II reduces the household waste generation 25 years to come (2017-2042) by 1.01 fold. Scenario III reduces household waste generation 25 years to come (2017-2042) by 2-fold. Scenario IV decreases household waste generation 25 years to come (2017-2042) of 2.82 times. This scenario is more effective to reduce the amount of household waste generation compared to the pessimistic and moderate scenario. It was concluded that, the average of household waste in Baubau City, based on the results of dynamic model simulation for 25 years (2017-2042) with the waste bank scenario, is having decreased by 1.01 times the total waste..
\end{abstract}

Keywords: Estimation, Dynamic Model, Waste Generation of Household. 


\section{PENDAHULUAN}

Sampah sering dianggap sebagai masalah dalam kehidupan manusia. Di satu sisi sampah merupakan bahan-bahan yang tidak bernilai ekonomis sehingga dibuang, disisi lain ada pihak yang menganggap sampah sebagai barang berguna. Jumlah sampah dan jenis sampah yang dihasilkan bervariasi untuk rumah tangga. Jumlah rumah tangga akan menentukan jumlah sampah yang harus diangkut oleh Dinas Kebersihan. Pengelolaan dalam pengangkutan sampah menjadi masalah tersendiri karena bila tidak tertangani dengan baik akan menyebabkan terjadinya timbulan sampah yang tidak terkehendaki dan pada akhirnya akan mencemari lingkungan (Sudradjat, 2008).

Perkembangan dan pertumbuhan kota metropolitan di beberapa negara berkembang telah menimbulkan permasalahan dalam hal pengelolaan sampah. Saat ini daerah perkotaan di Kawasan Asia mengeluarkan US\$ 25 milyar per tahun untuk pengelolaan 760.000 ton sampah per hari. Pengelolaan sampah diperkirakan akan terus meningkat menjadi US\$ 50 milyar pada tahun 2025 dengan proyeksi jumlah sampah sebesar 1,8 juta ton per hari (Alex, 2011).

Jika masalah sampah tidak ditangani sebagaimana mestinya, maka dapat menimbulkan berbagai masalah, sampai pada risiko bagi kesehatan manusia serta makhluk lainnya. Pengelolaan sampah yang baik merupakan suatu rangkaian

kegiatan yang mencakup pengumpulan, pengangkutan, pengelolaan, dan pembuangannya. Setiap kegiatan tersebut berkaitan antara satu dengan lainnya dan saling berhubungan timbal balik (Rizal, 2011).

Kota Bau-Bau secara administrasi baru terbentuk berdasarkan Undang-Undang nomor 13 tahun 2001 sehingga masih relatif muda, namun permasalahan yang dihadapi jauh lebih banyak dibanding usia pembentukannya. Masalah-masalah umum yang dihadapi Kota Baubau dalam pembangunan antara lain tercermin dari berbagai hal yang ada di masyarakat. Salah satu permasalahan tersebut berupa: kebersihan dan keindahan kota, terutama terjadi di wilayah pusat kota karena keterbatasan ruang kota sementara kegiatan yang ada sangat padat. Pada tahun 2014 jumlah penduduk Kota Bau-Bau yaitu 151.485 jiwa dengan jumlah timbulan sampah sebesar $364,53 \mathrm{~m}^{3} /$ hari. Volume sampah yang terangkut rata-rata

$96 \mathrm{~m} 3 /$ hari atau hanya sekitar 36,26\% sampah yang dapat tertangani oleh Kantor Kebersihan, berarti terdapat 63,74\% dari total timbulan sampah yang tidak terangkut ke TPA (Dinas Kebersihan Kota Baubau, 2016).

Volume sampah yang harus diangkut ke TPA semakin hari semakin besar dikarenakan semua sampah yang terkumpul harus diangkut ke TPA dan 
tidak ada upaya pengelolaan atau pemanfaatan sampah dalam bentuk daur ulang atau komposting di Kota Baubau. Oleh sebab itu diperlukan alternatif pengelolaan sampah kota Baubau. Pemodelan merupakan metode yang dibuat untuk memprediksi timbulan sampah yang akan terjadi jika diterapkan beberapa tidakan kontrol alternatif yang strategis sehingga diperoleh pilihan tindakan atau kebijakan yang tepat dalam usaha menekan jumlah timbulan sampah di Kota Baubau.

Dengan demikian diperlukan pendekatan model dinamis dengan menggunakan aplikasi STELLA yang bertujuan, pertama mendapat gambaran atau fenomena mengenai pengelolaan sampah dengan cara membuat "sistem model dinamis" pada sistem sampah perkotaan, dilanjutkan melakukan simulasi dengan menentukan dan mengubah-ubah variabel berpengaruh pada sistem / model yang dibuat sehingga dapat diketahui respon dari variabel yang diamati dengan harapan dapat berguna untuk pengambilan kebijakan atau keputusan pada instansi terkait. Model ini diharapkan dapat mengestimasi timbulan sampah Kota Baubau tahun 2017 hingga tahun 2042.

\section{BAHAN DAN METODE}

\section{Lokasi Penelitian}

Penelitian ini dilaksanakan pada tingkat kelurahan sebnayak delapan kelurahan yaitu Kelurahan Batulo Kecamatan Wolio,
Kelurahan wajo Kecamatan Murnum,

Kelurahan Karya Baru Kecamatan

Sorawolio, Kelurahan Lowu-Lowu

Kecamatan Palabusa, Kelurahan

Kadolomoko Kecamatan Kokalukuna,

Kelurahan Ngkari-Ngkari Kecamatan

Bungi, Kelurahan Labalawa Kecamatan

Betoambari dan Kelurahan Kaubula

Kecamatan Batupoaro dari tanggal 25 April -20 Mei 2017.

\section{Desain dan Variabel Penelitian}

Jenis penelitian adalah Cross Sectional dengan pendekatan model sistem dinamis yakni pengumpulan data untuk mendesain model yang bertujuan mendeskripsikan dan prediksi ke depan timbulan sampah rumah tangga di Kota Baubau.

\section{Populasi Sampel}

Populasi dalam penelitian ini adalah seluruh rumah yang ada di delapan kelurahan tersebut.Sampel dalam penelitian ini adalah rumah yang berada di kelurahan yang terpilih dengan prosedur simple random sampling dan besar sampel ditentukan dengan menggunakan rumus Lemeshow, 1991 sehingga diperoleh besar sampel 359 rumah.

\section{Pengumpulan Data}

Pengumpulan data terdiri dari data primer dan data sekunder.Data primer diperoleh dari pengamatan langsung di lokasi penelitian yang terdiri dari data mengenai karakterisitik responden, timbulan sampah tiap rumah dan data 
tentang status ekonomi wawancara salah satu penghuni rumah dengan kuesioner yang berisikan pertanyaan yang berhubungan dengan variabel penelitian dan lembar observasi. Data sekunder terkait timbulan sampah rumah tangga kota Baubau 2007 - 2015, data sampah yang dikelola di bank sampah dan di pembuatan kompos diperoleh dari Dinas Kebersihan Kota Baubau. Data laju pertumbuhan penduduk, jumlah penduduk dan jumlah KK dan jumlah anggota dalam KK yang diperoleh dari Badan Pusat Statistik Kota Baubau.

\section{Analisis Data}

Penelitian ini dilakukan melalui beberapa tahapan kegiatan, baik dalam bentuk penelitian pustaka, pengambilan dan pengolahan data maupun kegiatan analisis model dengan menggunakan STELLA 5.0

\section{HASIL}

\section{Skenario I}

Skenario I merupakan estimasi timbulan sampah rumah tangga pada tahun 2017-2042 tanpa intervensi atau membiarkan seperti kondisi eksisting (do nothing). Data timbulan sampah rumah tangga yang diperoleh selanjutnya disimulasi sampai 25 tahun yang akan datang (2017-2042). pada 25 tahun yang akan datang yaitu 2017 - 2042 timbulan sampah rumah tangga di Kota Baubau mengalami peningkatan rata - rata tiap peningkatan jumlah penduduk setiap tahunnya yang meningkat 1,02 kali lipat. Ditahun pertama timbulan sampah organik rumah tangga yang dihasilkan sebanyak $4.336 \mathrm{~m}^{3} /$ haripada tahun ke 10 timbulan sampah organik rumah tangga mengalami peningkatan sebanyak $5.398 \mathrm{~m}^{3} /$ hari dan ditahun ke 25 timbulan sampah organik rumah tangga mengalami peningkatan sebesar 1,43 kali lipat menjadi 7.775 $\mathrm{m}^{3} /$ hari. Rata - rata kenaikan timbulan sampah rumah tangga tiap tahunnya sebesar 0,99 kali lipat.

\section{Skenario II}

Hasil skenario optimis untuk timbulan sampah rumah tangga yang terus mengalami peningkatan hingga 25 tahun yang akan datang, tetapi dengan skenario bank sampah pada tahun ke 10 mampu menekan timbulan sampah rumah tangga hingga $26 \%$ dari total sampah dengan kelipatan 1,01 kali. Pada tahun ke 20 total sampah $9845,33 \mathrm{~m}^{3} /$ hari berkurang menjadi $7372,05 \mathrm{~m}^{3} /$ hari. Rata - rata tiap tahun timbulan sampah mengalami penurunan sebesar 33,50\%, sampah yang diolah pada bank sampah sebanyak $22,9 \%$ dari total sampah. Skenario ini lebih mampu menekan jumlah timbulan sampah rumah tangga dibandingkan dengan skenario pesimis dan moderat.

\section{PEMBAHASAN}

Timbulan sampah di Kota Baubau setiap tahunnya semakin meningkat seiring 
dengan meningkatnya jumlah penduduk, pola konsumsi dan tingkat kesejahteraan masyarakat. Jumlah sampah terbesar berasal dari rumah tangga yakni pada tahun 2015 menghasilkan sampah 345.324 m3. Sampah sering dianggap sebagai masalah dalam kehiduan manusia. Di satu sisi sampah merupakan bahan-bahan yang tidak bernilai ekonomis sehingga dibuang, disisi lain ada pihak yang menganggap sampah sebagai barang berguna.

Jumlah penduduk akan menentukan jumlah sampah yang harus diangkut oleh Dinas Kebersihan. Rata-rata setiap rumah di Kota Baubau menghasilkan sampah sebanyak $6 \mathrm{~kg} / \mathrm{hari}$ atau $0,18 \mathrm{~m} 3 /$ hari $(70 \%$ sampah organik dan $30 \%$ sampah anorganik). Pengelolaan dalam pengangkutan sampah dan ketersediaan TPS masih menjadi masalah tersendiri karena bila tidak tertangani dengan baik akan menyebabkan terjadinya penimbulan sampah yang tidak terkehendaki dan pada akhirnya akan mencemari lingkungan.

Saat ini penanganan sampah di Kota Baubau merupakan tanggung jawab Dinas Kebersihan, sedangkan masyarakat hanya menjadi produsen sampah.Bila terjadi permasalahan dalam penanganan sampah (sampah tidak terangkut) masyarakat cenderung menyalahkan Dinas Kebersihan, padahal masyarakat dapat ikut berperan dalam pengelolaan sampah. Masyarakat sebagai produsen sampah dapat berpartisipasi dalam mengurangi jumaah sampah, memitân sampah dan megolah kembali menjadi barang yang berguna dan bernilai ekonomis. Partisipasi masyarakat dalam pengelolaan sampah dapat membantu pemerintah dalam mewujudkan kota yang bersih.

Skenario model dilakukan dengan beberapa skenario dan dianalisis berdasarkan skenario dasar (kondisi eksisting) sebelumnya dengan asumsi tidak ada pengendalian yang dilakukan dan tidak ada perubahan kebijakan. Skenario dasar merupakan skenario do nothing dimana tidak dilakukan intervensi terhadap model sehingga kondisi model merupakan kondisi saat ini tanpa adanya upaya atau strategi untuk perbaikan sistem (Mandra, 2013).

Skenario yang diterapkan yaitu skenario bank sampah dan skenario pengomposan. Skenario pertama (I) merupakan skenario do nothing yang menjelaskan rona awal sebelum dilakukan intervensi kebijakan. Kondisi berjalan sesuai dengan peraturan yang masih berlaku saat ini yang pada umumnya tidak terlaksana dengan baik.Opersional skenario ini adalah menyelesaikan kasus yang tampak dilapangan. Berdasarkan hasil simulasi menunjukkan bahwa pada 25 tahun yang akan datang (2017-2042) timbulan sampah rumah tangga di Kota Baubau mengalami peningkatan. sebesar $2,66 \%$ seiring dengan peningkatan jumlah penduduk setiap tahunnya. Ditahun pertama timbulan sampah organik rumah 
tangga yang dihasilkan sebanyak 4.336 $\mathrm{m}^{3} /$ hari. Pada tahun ke 10 timbulan sampah organik rumah tangga mengalami peningkatan sebanyak $5.398 \mathrm{~m}^{3} /$ hari dan ditahun ke 25 timbulan sampah organik rumah tangga mengalami peningkatan 1,43 kali lipat menjadi $7.775 \mathrm{~m}^{3} /$ hari .

Skenario II terkait dengan ketersediaan dan pemanfaatan Bank sampah.Bank sampah mengajarkan masyarakat untuk memilah sampah, menumbuhkan kesadaran masyarakat mengolah sampah secara bijak agar dapat mengurangi sampah yang diangkut ke TPA. Selain itu warga yang menyerahkan sampahnya akan memperoleh tambahan penghasilan untuk kemandirian ekonomi warga dapat digunakan usaha simpan pinjam seperti koperasi dan terwujudnya kesehatan lingkungan.

Upaya menjaga kelestarian lingkungan harus bermula dari individu dengan memulai dengan melakukan hal- hal yang kecil.Perubahan yang dilakukan kemudian dapat ditularkan menjadi kebiasaan dalam keluarga ataupun masyarakat, sehingga terjadi perubahan besar. Perubahan cara berpikir masyarakat mengenai pengelolaan sampah rumah tangga untuk mengurangi sampah di sumber melalui pertisipasi warga harus di integrasikan ke dalam proyek bank sampah yang berbasis masyarakat (Singhirunnsorn, 2012). sampah yang ada di Kota Baubau sebanyak 1 unit namun tidak berada dibawah pengelolaan Dinas Kebersihan (pengelolaan Informal). Pada skenario II ini Dinas Kebersihan membuat bank sampah baru di tingkat TPS yang berada di delapan kecamatan Kota Baubau. Bank sampah dilakukan ditingkat TPS (Tempat Penampungan Sementara) karena rata-rata masyarakat Kota Baubau mengumpulkan sampahnya di TPS.Dengan kondisi wilayah yang tidak memungkinkan untuk masuknya mobil pengangkut sampah ditiap-tiap rumah warga.

Dari hasil skenario pesimis bank sampah yang dijalankan, timbulan sampah berkurang hingga 1,01 kali lipat lebih tinggi dibandingkan dengan skenario bank sampah moderat yang hanya mengurangi sampah hingga 0,81 kali lipat, sedangkan pada hasil dari skenario bank sampah optimis yang dijalankan, timbulan sampah di Kota Baubau rata - rata mengalami penurunan sebesar 33,09\% setiap tahunnya selama 25 tahun kedepan. Dengan adanya bank sampah dapat mengurangi timbulan sampah di Kota Baubau sebelum diangkut Ke TPA (Tempat Pembuangan Akhir).Bank sampah juga dapat dijadikan solusi untuk mecapai permukiman yang bersih dan nyaman bagi warganya.

Seperti penelitian yang dilakukan (Novianti, 2014) Adanya bank sampah diakui sebagian responden telah 
memberikan perbaikan kebersihan

lingkungan yaitu sebanyak 30 responden dan juga memberikan manfaat langsung dengan berkurangnya timbulan sampah di lingkungan yang diakui oleh 28 responden. Dengan Pola ini maka warga selain menjadi disiplin dalam mengelola sampah juga mendapatkan tambahan pemasukkan dari sampah - sampah yang mereka kumpulkan.Dengan adanya bank sampah, keberadaan sampah lebih berarti karena lebih baik ditabungkan daripada terbuang secara sia-sia atau dibakar.Oleh karena itu, keberadaan bank sampah juga dapat meningkatkan kenyaman lingkungan dengan semakin berkurangnya warga yang membakar sampah.Sampah sudah menjadi ancaman yang serius.Bila tidak dikelola dengan baik.

Menurut UU No. 18 Tahun 2008 tentang pengelolaan sampah, kini perlu perubahan cara pandang masyarakat mengenai sampah dan cara memperlakukan atau mengelola sampah. Cara pandang masyarakat pada sampah seharusnya tidak lagi memandang sampah sebagai hasil buangan yang tidak berguna.Sampah seharusnya dipandang sebagai suatu yang mempunyai nilai guna dan manfaat. Dalam rangka melaksanakan peraturan pemerintah No. 81 tahun 2012 tentang pengelolaan sampah rumah tangga dan sampah sejenis sampah rumah tangga, maka praktek mengolah dan manfaatkan sampah harus menjadi Tangkah nyata dan mengelola sampah.

Masyarakat harus meninggalkan cara lama yang hanya membuang sampah dengan mendidik dan membiasakan masyarakat memilah, memilih dan menghargai sampah sekaligus mengembangkan ekonomi kerakyatan melalui pengembangan bank sampah. Hal ini khususnya dalam pengelolaan sampah rumah tangga berbasis komunitas dikarenakan sumber sampah domestik perlu dikelola secara mandiri (Mardikato, 2012).

Pengetahuan, sikap dan keterampilan warga mengelola sampah rumah tangga untuk melakukan daur ulang juga menjadi hal penting dalam pengelolaan sampah (Basriyatna, 2007). Adaptasi bank sampah pada setiap komunitas sangat ditentukan partisipasi warga yang juga akan menentukan keberlanjutan bank sampah sehingga pengelolaan berbasis komunitas menjadi perlu diperhatikan ( Cecep, 2012). Inovasi pengolahan sampah dengan program bank sampah menjadi inovasi ditingkat akar rumput yang dapat meningkatkan pendapatan masyarakat perkotaan.

Hasil penelitian Damanhuri (2012) menyimpulkan bahwa sistem pengelolaan sampah dengan metode Bank Sampah dapat mereduksi sampah rata-rata sekitar 0,14kg/orang/hari. Berkaitan dengan hal tersebut, bila penanganan sampah 
dilakukan secara simultan atau dilakukan secara terintegrasi dengan progresif pada sampah organik dan sampah anorganik maka diharapkan dapat mereduksi sampah dalam jumlah yang sangat besar.

\section{KESIMPULAN DAN SARAN}

Estimasi rata - rata timbulan sampah rumah tangga di Kota Baubau berdasarkan hasil simulasi model dinamis selama 25 tahun (2017-2042) tanpa tindakan pengendalian mengalami kenaikan tiap tahunnya sebesar 0,99 kali lipat.Estimasi rata - rata timbulan sampah rumah tangga di Kota Baubau berdasarkan hasil simulasi model dinamis selama 25 tahun (2017-2042) dengan skenario bank sampah mengalami penurunan sebesar 1,01 kali lipat dari total sampah. Maka dari itu diharapkan pemerintah atau instansi terkait melakukan upaya pengendalian untuk menekan laju peningkatan timbulan sampah rumah tangga di Kota Baubau. Masyarakat diharapkan lebih kreatif dan inovatif dalm mengurangi timbulan sampah seperti memberi informasi kepada msyarakat yang belum paham terhadap sampah dan lingkungan, mendirikan bank sampah dikawasan tempat tinggal mereka.

\section{DAFTAR PUSTAKA}

Alex. (2011). Kajian Partisipasi Masyarakat Yang Melakukan Pengelolaan Persampahan 3R di Kelurahan Ngaliyan dan Kalipancur Kota Semarang. Tesis(Online).http://eprints.undi
p.ac.10/24266/1/ALFIANDRA.p df, Diakses 7 Februari 2017.

Basriyatna. (2007). Memanen Sampah. Yogyakarta: Kanisius

Cecep. D. S (2012). Teknologi

Pengelolaan Daur Ulang sampah. Gosyen

Publishing. Yogyakarta

Damanhuri, E. 2010.Diktat Pengelolaan Sampah. Teknik Lingkungan Institut Teknologi Bandung (ITB): Bandung.

Dinas Kebersihan Kota Baubau.Laporan Tahunan.(2016).

Mandra. (2013). Pengolahan Sampah Terpadu, Yogyakarta: Kanisius.

Mardikato. (2012). Desain Sistem Pengelolaan Sampah Melalui Pemilahan Sampah Organik Dan Anorganik Berdasarkan Persepsi Ibu - Ibu Rumah Tangga. (Online).http://www.jurnal.ftumj.ac .id/index.php/konversi/article/view/ 670/636, Diakses 10 Februari 2017 Novianti. M. (2014). Mengintip Sistem Pengelolaan Sampah di Negara Мaju

(Online).http://mjeducation.com.

Di akses 10 Februari 2017

Rizal. M. (2011). Analisis Pengelolaan

Persampahan Perkotaan (Studi

Kasus Pada Kelurahan Boya Kecamatan Banawa Kabupaten Donggala).(Online).http://jurnal.un tad.ac.id/jurnal/index.php/SMART EK/article/viewFile/.../532, Diakses 7 Februari 2017.

Singhirunnusorn. (2012). Peran Bank Sampah Dalam Efektivitas Pengelolaan Sampah (Studi Kasus Bank Sampah Malang). (Online) https://jurnal.dpr.go.id/index.php/as pirasi/article/view/447/344Diakses 10 Februari 2017

Sudradjat. (2008). Mengelola Sampah Kota. Penebar Swadaya: Jakarta.

Undang-Undang Nomor 18 Tahun 2008 Tentang Pengelolaan Sampah (Online).http://www.menlh.go.id/D ATA/UU18-2008.pdf, Diakses 10 Februari 2017. 